\title{
Long-term field study on stabilization of contaminated wastes by growing clonally reproduced Silene vulgaris calamine ecotype
}

\author{
Ewa Hanus-Fajerska • Krystyna Ciarkowska • \\ Ewa Muszyńska
}

Received: 7 September 2018 / Accepted: 20 February 2019 /Published online: 29 March 2019

(C) The Author(s) 2019

\begin{abstract}
Aims Pseudo-metallophyte Silene vulgaris frequently colonizes polluted areas. We investigated whether plants obtained under in vitro conditions can be used to form long-term communities on zinc-lead tailings rich in cadmium. To this end, we checked the species stabilization capacity and biochemical properties of the area subjected to long-term cultivation of a local $S$ vulgaris ecotype. We focused on evaluation of its ability to accumulate trace metals (TMs) after 10-year cultivation period.

Methods The calamine $S$. vulgaris ecotype was propagated in vitro and acclimatized to ex vitro conditions in a greenhouse. The plants were then replanted on plots created on the flotation settler heavily polluted with $\mathrm{Zn}, \mathrm{Pb}$ and $\mathrm{Cd}$. The capacity of trace metal accumulation in plant material was checked based on
\end{abstract}

Responsible Editor: Antony Van der Ent.

E. Hanus-Fajerska $(\square)$

Unit of Botany and Plant Physiology, Institute of Plant Biology and Biotechnology, Faculty of Biotechnology and Horticulture, University of Agriculture in Krakow, A1. 29 Listopada 54,

31-425 Krakow, Poland

e-mail: e.hanus-fajerska@urk.edu.pl

K. Ciarkowska

Department of Soil Science and Soil Protection, Faculty of Agriculture and Economics, University of Agriculture in Krakow, Al. Mickiewicza 21, 31-120 Krakow, Poland

E. Muszyńska

Department of Botany, Faculty of Agriculture and Biology,

Warsaw University of Life Sciences - SGGW, Nowoursynowska 159, 02-776 Warsaw, Poland translocation (TF) and bio-concentration (BCF) factors. Nutrient, TMs content, and enzyme activity of substrate were determined after 1 and 10 years of cultivation and compared with the properties of bare flotation waste. Results Numerous plants obtained through vegetative in vitro propagation were planted in the field after a short hardening period. Cultivation of plant material obtained this way increased microbial activity, $\mathrm{C}$ concentration, and reduced TM contents in the substrate. TF calculated after the first season of $S$. vulgaris cultivation was similar for all metals and amounted to about $40 \%$. After 10 years, it was the highest for $\mathrm{Cd}(50 \%)$. Independently of the experiment duration, BCF for $\mathrm{Zn}$ and $\mathrm{Pb}$ was $<1$, while for $\mathrm{Cd}$ it reached about 1.4 after 10 years for both shoots and roots.

Conclusions The calamine $S$. vulgaris ecotype cloned in tissue culture proved useful material for stabilization of trace metal contaminated post-flotation wastes. Ten years of its cultivation in tailings rich in $\mathrm{Zn}, \mathrm{Pb}$ and $\mathrm{Cd}$ contributed to humus layer formation and increase in microbial activity in the substrate. Thus, the beginning of soil formation was noticed in heavily polluted tailings.

Keywords Bladder campion · Mass-propagation · $\mathrm{Zn}-\mathrm{Pb}$ flotation wastes $\cdot$ Remediation $\cdot$ Enzyme activity
Abbreviations
BA
Benzyladenine
IAA
Indole-3-acetic acid
IBA
Indole-3-butyric acid
NAA
$\alpha$-naphtaleneacetic acid
PGRs 


$\begin{array}{ll}\text { FW } & \begin{array}{l}\text { Flotation wastes, waste material obtained } \\ \text { in the process of flotation enrichment } \\ \text { of zinc-lead poly-metallic ores }\end{array} \\ \text { ICP-OES } & \begin{array}{l}\text { Inductively coupled plasma optical } \\ \text { emission spectrometry }\end{array} \\ \text { DHA } & \begin{array}{l}\text { Dehydrogenase activity } \\ \text { Inv }\end{array} \\ \text { Urea } & \text { Urease activity } \\ \text { EAI } & \begin{array}{l}\text { Enzyme activity index } \\ \text { Translocation factor }\end{array} \\ \text { BCF } & \text { Bioconcentration factor }\end{array}$

\section{Introduction}

Mining of metals and metallurgy industries have resulted in environmental pollution on the global scale (Farmer and Farmer 2000; Cai et al. 2009; Doumas et al. 2018; Sun et al. 2018). In Poland, heavy industry is located mainly in the southern part of the country and it represents one of the major European zinc-lead mining areas (Coppola et al. 2009). In the Olkusz Ore-Bearing Region belonging to the Silesian-Cracow district in southern Poland, metal mining and processing activities, dating back to the medieval times, focused mainly on zinc-lead ores. Abundant zinc-lead sulfides, a series of oxidized $\mathrm{Zn}-\mathrm{Pb}$ minerals, and galmei ores that contain silver, cadmium and admixtures of other elements have been utilized for centuries in this region. Currently, ore processing in a local mining-metallurgy factory uses a flotation procedure to recover $\mathrm{Zn}$ and $\mathrm{Pb}$ from ores. This approach generates about one and a half thousand tons of waste annually (Cichy et al. 2016). Satisfactory solutions for reducing the volume of crumbled waste rock deposits from mining processes and post flotation waste are yet to be fully developed. The dumping ground in a shape of a vast post flotation tailing pond covers currently the area of over 100 ha (Pierwoła 2015; Motyka et al. 2017).

Revitalization of degraded terrains may be carried out as previously scheduled reclamation or assisted succession masterminded by an interdisciplinary team (Chigbo et al. 2013; Ciarkowska et al. 2017). An ecologically safe and economically advantageous solution would be reinforcing plant communities derived from the secondary succession in order to accelerate recovery of the local vegetation (Ciarkowska and Gambuś 2005; Ciarkowska and Hanus-Fajerska 2008; Pardo et al. 2018). This is particularly important for soilless areas, such as the tailing ponds of post flotation wastes, which are particularly difficult to stabilize and develop a vegetation cover. The only reasonable solution in this case would include planting the representatives of the local flora. An important step in the rehabilitation of mining soilless areas is initiation of soil-forming processes. Covering such terrains with soil limits water and wind erosion by enhancing the soil water capacity. It also limits metals leaching to the surrounding environment. Potential indicators of anthropogenic activities in soil environments are enzymes that in industrialized sites with high metal loads usually show low activity indicating low microbiological diversity. Therefore, an increase in enzyme activity may be regarded as a manifestation of successful rehabilitation efforts (Ciarkowska et al. 2014; Hagmann et al. 2015).

The conditions for the occurrence of calamine flora are quite well documented (Dechamps et al. 2011; Rola et al. 2015; Woch et al. 2017). A prevalent feature of such vegetation is a significant share of so-called metallophytes, i.e. plant species that grow on substrates geochemically enriched with metal ions and selectively accumulate different trace metals (Szarek-Łukaszewska and Grodzińska 2011; Ciarkowska et al. 2017). Such species seem to be the best candidates for direct application on terrains degraded by strong anthropogenic pollution. This assumption is supported by some ecophysiological and phytochemical studies carried out by many research teams (Wierzbicka and Panufnik 1998; Ernst et al. 2000; Alvarez et al. 2003). The calamine population of Silene vulgaris is adapted to grow on industrial dumps and waste materials generated during processing of $\mathrm{Zn}-\mathrm{Pb}$ ores (Chardonnes et al. 1998; Wierzbicka and Panufnik 1998; Nadgórska-Socha et al. 2013). This was also confirmed in our preliminary experiment (Ciarkowska and Hanus-Fajerska 2008). Moreover, considering totipotency of living plant cells, enhanced multiplication efficiency under in vitro conditions could be easily achieved. This approach was exploited during multiplication of valuable plant material for resolving some basic scientific aims, i.e. in studies on drought and nutrient deficiency tolerance in both self and cross-pollinated lines of $S$. vulgaris from northern Hesse population in Germany (Sandner and Matthies 2016, 2018). Thus, we hypothesized that biotechnological tools were appropriate to propagate Silene vulgaris efficiently, and that propagated material should successfully stabilize flotation tailings. Considering that it is justified to produce the mass-propagated plant material to be applied in a remediation scheme on the post- 
flotation pond localized in southern Poland, we designed an appropriate experimental scheme. Our first task was to evaluate the in vitro technique and obtain abundant rebalanced material representing calamine population of the studied species. A key stage was a long-term field experiment in which suitability of the propagated $S$. vulgaris ecotype to grow on flotation tailings was evaluated in two aspects - its remediation potential and enhancement of biochemical and chemical properties of tailings.

\section{Material and methods}

Laboratory and greenhouse experiments

regarding mass-propagation and further hardening

of regenerated plants

\section{Propagation stage}

As an initial plant material, capsules with seeds representing metal-tolerant population of bladder campion (Silene vulgaris (Moench.) Garcke, Caryophyllaceae Juss.) were sampled in July 2006. They were harvested from plants growing on a hundred year old waste heap localized in the Olkusz Ore-Bearing District besides the premises dealing with metallic ores mining. The collected seeds were used to initiate in vitro cultures. They were surface sterilized in $70 \%$ ethanol for $1 \mathrm{~min}$., then in $1.5 \%$
$\mathrm{NaOCl}$ with $0.01 \%$ Tween 20 for 25 min., and rinsed several times with sterile distilled water. Afterwards, they were placed in aseptic conditions on a modified Murashige and Skoog medium, containing salts with macro- and microelements, vitamins, and amino acids as per Murashige and Skoog (MS) (1962) but diluted to a quarter strength $(1 / 4 \mathrm{MS})$, and supplemented with $30 \mathrm{~g} \mathrm{dm}^{-3}$ sucrose. $\mathrm{pH}$ was adjusted to 5.8 prior to the addition of agar $(6.5 \% \mathrm{w} / \mathrm{v})$. The primary explants used to initiate shoot culture were shoot tips with apical meristem, excised from the emerged seedlings. During the shoot multiplication stage, diverse combinations of culture ingredients were applied (Table 1). The following types and concentrations of plant growth regulators (PGRs) were tested in the propagation medium: 0.1$0.5 \mathrm{mg} \mathrm{dm}^{-3} \alpha$-naphtaleneacetic acid (NAA), $0.1-$ $0.5 \mathrm{mg} \mathrm{dm}^{-3}$ indole-3-butyric acid (IBA), and 0.5$1.0 \mathrm{mg} \mathrm{dm}^{-3}$ benzyladenine (BA). Shoot explants about $15 \mathrm{~mm}$ long were randomly taken from the previously established stock culture and dipped into the medium with their basal parts. $\mathrm{pH}$ of the micro-cloning medium was 6.4. For solid media, 8\% (w/v) agar A-1269 (Sigma Chem. Co, USA) was used. Autoclaving time was $15 \mathrm{~min}$. at $121{ }^{\circ} \mathrm{C}$. We used cylindrical culture flasks of $200 \mathrm{ml}$ capacity filled with $20 \mathrm{ml}$ of the culture medium. Each flask harboured six explants and ten replications were run. All experiments were repeated three times. Micropropagated shoots were evaluated every week and multiplication coefficients were calculated as the

Table 1 Impact of $\alpha$-naphtaleneacetic acid (NAA), indole-3-butyric acid (IBA) and benzyladenine (BA) on micropropagation of Silene vulgaris

\begin{tabular}{|c|c|c|c|c|}
\hline $\begin{array}{l}\text { Auxin/cytokinin level } \\
{\left[\mathrm{mg} \mathrm{dm}^{-3}\right]}\end{array}$ & Propagation coefficient & $\begin{array}{l}\text { Number of shoots fit } \\
\text { for root initiation }\end{array}$ & $\begin{array}{l}\text { Number } / \% \text { of } \\
\text { rooted shoots }\end{array}$ & $\begin{array}{l}\text { Mean number**/percent of plants } \\
\text { acclimatized to ex vitro conditions }\end{array}$ \\
\hline $\begin{array}{l}\text { I: } 0.1 \mathrm{NAA} \\
0.5 \mathrm{BA}\end{array}$ & $7.8 \pm 0.88 \mathrm{a}^{*}$ & $372 * *$ & $346 * * / 91.9 \%$ & $\begin{array}{l}310 \pm 3.49 \mathrm{ab} \\
/ 89.5 \% * * *\end{array}$ \\
\hline $\begin{array}{l}\text { II: } 0.3 \text { NAA } \\
0.7 \mathrm{BA}\end{array}$ & $8.02 \pm 1.34 \mathrm{a}$ & 377 & $340 / 90.1 \%$ & $\begin{array}{l}294 \pm 6.43 \mathrm{a} \\
/ 86.4 \%\end{array}$ \\
\hline $\begin{array}{l}\text { III: } 0.5 \text { NAA } \\
1.0 \mathrm{BA}\end{array}$ & $8.4 \pm 1.49 \mathrm{ab}$ & 376 & $333 / 88.6 \%$ & $\begin{array}{l}290 \pm 6.81 \mathrm{a} \\
/ 870 \%\end{array}$ \\
\hline $\begin{array}{l}\text { IV: } 0.1 \mathrm{IBA} \\
0.5 \mathrm{BA}\end{array}$ & $8.3 \pm 4.13 \mathrm{ab}$ & 384 & $357 / 92.9 \%$ & $\begin{array}{l}351 \pm 7.18 \mathrm{c} \\
/ 927 \%\end{array}$ \\
\hline $\begin{array}{l}\mathrm{V}: 0.3 \mathrm{IBA} \\
0.7 \mathrm{BA}\end{array}$ & $8.6 \pm 0.98 \mathrm{ab}$ & 402 & $370 / 92.0 \%$ & $\begin{array}{l}338 \pm 4.91 \mathrm{ab} \\
/ 91.3 \%\end{array}$ \\
\hline $\begin{array}{l}\text { VI: } 0.5 \text { IBA } \\
1.0 \mathrm{BA}\end{array}$ & $9.2 \pm 1.27 \mathrm{~b}$ & 426 & $383 / 89.9 \%$ & $\begin{array}{l}353 \pm 5.79 \mathrm{c} \\
/ 92.1 \%\end{array}$ \\
\hline
\end{tabular}

*Means followed by the same letter do not differ significantly at $p \leq 0.05$

**From 10 replications that is from 60 primary explants

$* * *$ Percent of rooted shoots 
number of regenerated shoots per the initial explant. Temperature in the culture room was set to $24{ }^{\circ} \mathrm{C} \pm 2^{\circ}$ (day) and $18{ }^{\circ} \mathrm{C} \pm 2^{\circ}$ (night). Photosynthetically active radiation (PAR) at the culture level was adjusted to $60 \mu \mathrm{mol} \mathrm{m}{ }^{-2} \mathrm{~s}^{-1}$, with $16 / 8 \mathrm{~h}$ photoperiod provided with cool-white fluorescent light.

\section{Rooting of shoots and plant hardening}

The best developed micro-shoots (about $30 \mathrm{~mm}$ long) were chosen for rooting. Root regeneration was conducted in culture tubes in basic Murashige and Skoog semi-solid medium without PGRs. The rooted microplants were removed from the culture vessels, washed with sterile water to remove agar, and planted into $5 \mathrm{~cm}$ diameter pots filled with sterile substrate made up of garden soil, perlite, and flotation wastes in 1:1:1 ratio $(v / v)$. The first hardening phase lasted for 3 weeks and plants were kept in a growth chamber at $70 \% \mathrm{RH}$, $24{ }^{\circ} \mathrm{C} \pm 2$, under PAR $80 \mu \mathrm{mol} \mathrm{m} \mathrm{s}^{-2}, 16 / 8 \mathrm{~h}$ photoperiod. Plantlets, protected with plastic caps, were sprinkled every day with sterile distilled water. Initially established plants were transferred for another 3 weeks to a shaded mist chamber in the University Greenhouses (RH $50 \%, 28{ }^{\circ} \mathrm{C} \pm 2$ ) for a second phase of hardening in plastic rings filled with the flotation wastes (FW) taken from the settling pond. The material hardened this way was ready to be replanted in the field. The percentage of hardened plants was evaluated after 21 days of acclimation to ex vitro growth. Microscopic observations were performed at the end of the acclimation to ex vitro conditions and compared to the material obtained as a result of generative propagation. Histological analysis included vegetative organs of $\mathrm{R}_{0}$ regenerates, i.e. the regenerates of the first generation, following 21 days of acclimation to ex vitro conditions. The sections were analyzed with Nicon Eclipse C400 microscope integrated with JVC Digital camera and Image Pro-Plus Program.

Field experiment settings

\section{Establishing experimental plots}

The study area was situated in the Olkusz Ore-Bearing District, in Boleslaw commune (N 50 17'33', E 19²8' $\left.14^{\prime \prime}\right)$. Field investigations were carried out in the years 2007-2017. Three experimental plots, $6 \mathrm{~m}^{2}$ each, were located within a flat part of the post-flotation settler. A detailed description of the mining history and settler formation was published by Ciarkowska (2017). In the middle of May 2007, we planted on each plot 72 plants obtained by mass propagation and contained in plastic rings $(10 \mathrm{~cm}$ in diameter and $30 \mathrm{~cm}$ tall), filled with about $1 \mathrm{~kg}$ of FW. Each plastic ring comprised two plants. We used a total of 216 plants, grown in optimal conditions worked out during experimental masspropagation stage. The plants used in the field experiment were obtained from a single donor plant, so they constituted a specific clone described as L0 (from the first letter of Polish generic plant name). Designed row spacing was $25 \times 25 \mathrm{~cm}$. The plants were abundantly watered only after planting. Then they were cultivated without additional watering and without fertilizing. The experimental plots were checked every April, June, August and October of the growing season. During the experiment, we were removing all remaining or emerging vegetation from around the plastic rings.

\section{Sampling of substrate and plant material}

Flotation waste used as the substrate for the cultivation of S. vulgaris was analyzed three times: before the experiment (FW), after the first growing period - FW1 (without plants) and FW1S (with plants), and after 10 years FW10 (without plants) and FW10S (with plants). FW1 and FW10 samples were taken from around the plastic rings. Each time three composite samples, one from each experimental plot, were taken to examine the substrate properties. FW, FW1 and FW10 samples were taken from a depth of $0-30 \mathrm{~cm}$, while after the plant cultivation (FW1S and FW10S) we examined separately two layers: 0-10 $\mathrm{cm}$ and $10-30 \mathrm{~cm}$. Substrate samples were air dried, sieved through $2 \mathrm{~mm}$ mesh, and stored at room temperature until analysis.

The first batch comprising 18 plants (6 from each plot) was harvested after the first growing season and the second batch (18 plants) taken in the same way after 10 years. The remaining plants were left to grow on. Plants collected after the first growing season and at the end of the experiment were thoroughly rinsed with distilled water, roots and shoots separated and oven dried $\left(105^{\circ} \mathrm{C}\right)$ for $12 \mathrm{~h}$ and weighed to their dry mass.

\section{Laboratory analyses}

Soil reaction was determined potentiometrically in soilwater 1: 2.5 suspension. The levels of total nitrogen and 
carbon were analyzed in solid homogenized substrate samples with the use of TOC-TN 1200 Thermo Euroglas apparatus. The level of organic carbon was calculated as a difference between total and inorganic carbon. Total contents of $\mathrm{P}, \mathrm{K}, \mathrm{Mg}, \mathrm{Zn}, \mathrm{Pb}$ and $\mathrm{Cd}$ were determined in the substrate samples. The samples ( $2 \mathrm{~g}$ ) were digested in a mixture of concentrated nitric and perchloric acids. The elemental analyses were performed in solutions with the use of an inductively coupled plasma atomic emission spectrophotometer Perkin-Elmer model Optima 7300 DV (ICP-OES). Quality of the determinations was verified based on the results from trace metal determinations obtained for the internal standard and the certified reference material CRM023-050 - Trace Metals - Sandy Loam 7 (RT Corporation).

We measured substrate activity of dehydrogenase (DHA), urease (Urea), and invertase (Inv). DHA activity was established colorimetrically after incubation of the substrate samples for $24 \mathrm{~h}$ at $37^{\circ} \mathrm{C}$ with a 2,3,5-triphenyltetrazolium chloride solution (TTC). The intensity of coloration was measured with a Beckman DU 600 spectrophotometer at $450 \mathrm{~nm}$ (Cassida et al. 1964).

Urease activity was determined after incubation of the substrate samples for $2 \mathrm{~h}$ at $37{ }^{\circ} \mathrm{C}$ with a urea solution. The amount of ammonia left after urea hydrolysis was determined via distillation of ammonia nitrogen from the sample extract using a Kjeltec apparatus (Tabatabai and Brenner 1972).

Inv activity was established calorimetrically after incubation of the substrate samples for $24 \mathrm{~h}$ at $37^{\circ} \mathrm{C}$ with a sucrose solution. The intensity of coloration was measured with a Beckman DU 600 spectrophotometer at $540 \mathrm{~nm}$ (Frankenberger and Johanson 1983).

Samples $(2 \mathrm{~g})$ of the plant material were incinerated in a muffle furnace at $460{ }^{\circ} \mathrm{C}$ for $12 \mathrm{~h}$. The ash was dissolved in $\mathrm{HNO}_{3}(1: 2)$ and $\mathrm{Zn}, \mathrm{Pb}$ and $\mathrm{Cd}$ contents were analysed with ICP-OES.

\section{Data handling}

Enzyme activity index of the substrate (EAI) was calculated as a geometric mean, a general index to integrate information from variables that have different units and range of variation (Paz-Ferreiro et al. 2012):

$$
\mathrm{EAI}=\sqrt[3]{D H A \cdot U r e \cdot I A}
$$

One translocation factor $\left(\mathrm{TF}^{1}\right)$ was used to evaluate the ability of $S$. vulgaris to accumulate metals in the shoots, using dried shoot and root biomass collected after 1 year of plant cultivation and at the end of the experiment (after 10 years). $\mathrm{TF}^{1}$ was calculated separately for each metal $(\mathrm{Me})$ :

$\mathrm{TF}^{1} \%=\frac{\text { Me in shoots }}{\text { Me in }(\text { shoots }+ \text { roots })} \times 100$

Another translocation factor $\left(\mathrm{TF}^{2}\right)$, which expresses plant ability to transfer metals from roots to shoots, was defined as the ratio of metal concentration in the shoots vs. the roots and was also calculated using dry shoot and root biomass after one and 10 years, separately for each metal:

$\mathrm{TF}^{2}=\frac{\text { Me in shoots }}{\text { Me in roots }}$

A bioconcentration factor (BCF) was calculated to measure the ability of each plant organ to accumulate metals from the substrate:

$\mathrm{BCF}=\frac{\text { Me in plant organ }}{\text { Me in substrate }}$

Statistical analyses

The data obtained under in vitro and greenhouse conditions were subjected to one way ANOVA analysis (STATISTICA. PL v 12.0, StatSoft Inc. 2014, Poland), and a post-hoc Fisher's test was used to reveal statistically significant differences between means at $p \leq 0.05$. The values marked with the same letters are not significantly different.

One-way analysis of variance (ANOVA) was also applied to determine the differences in the examined substrates grouped according to the time passed: flotation wastes before the experiment establishment (FW), after the first year (FW1), after the first year of the plant cultivation (FW1S), after 10 years (FW10), and after 10 years of the plant cultivation (FW10S). In order to estimate the least significant differences between the mean values of homogenous groups, the post-hoc test with the Bonferroni correction (at $p<0.05$ ) was used. Homogeneity of variance (Levene test) and normality of data were tested as per ANOVA assumptions. When the distribution of data deviated from normal, transformations $(\ln )$ were used to normalize the data. Factor analysis (FA) was applied to specify the groups of variables 
(substrate properties) influenced by the main factors. In order to make the factors more easily interpretable, the Varimax rotation was performed. Pearson's linear correlation coefficients and standard deviations (SD) were also calculated.

\section{Results}

Shoot mass-propagation

Decontaminated seeds obtained from plants representing calamine population of Silene vulgaris, growing in the productive sector of metallic ores mining and converting facility (Fig. 1a, b), retained their vitality. The seed germination rate amounted to $80-85 \%$ and surface decontamination resulted in numerous sterile seedlings emerging in about 10 days on $1 / 4$ MS. Mean micro-propagation coefficient differed in the media supplemented with IBA/ NAA and BA. After 42 days, i.e. 12 days of culture stabilization and of 30-day passage period, it ranged between 7.8 and 9.2 from a single explant. The highest coefficient of vegetative propagation, i.e. nine stems from the initial explant, was obtained for the proliferation medium supplemented with $0.5 \mathrm{mg} \mathrm{dm}^{-3}$ IBA and $1.0 \mathrm{mg} \mathrm{dm}^{-3} \mathrm{BA}$. This treatment yielded the highest number of 459 shoots of different length, of which 426 shoots exceeded $20 \mathrm{~mm}$ and were appropriate for rooting (Table 1). The remaining 33 shoots were rejected due to too slow growth rate. Regardless of significant differences in the number of shoots obtained from individual treatments, the number of shoots ready to be rooted (exceeding $20 \mathrm{~mm}$ ) was similar for all treatments.
Therefore, if we take the number of rooted shoots ready to be transplanted into a pot as a criterion of the propagation success, the combination of IBA and BA was more effective than NAA and BA (Table 1).

\section{Shoot rooting and hardening of plants}

We produced the highest number of shoots suitable for the next step of the study in the medium for bladder campion propagation (Table 1) supplemented with $0.1 \mathrm{mg} \mathrm{dm}^{-3}$ IBA and $0.5 \mathrm{mg} \mathrm{dm}^{-3} \mathrm{BA}$ or $0.5 \mathrm{mg} \mathrm{dm}^{-3}$ IBA and $1.0 \mathrm{mg} \mathrm{dm}^{-3}$ BA. Supplementation of the propagation medium with $0.3 \mathrm{mg} \mathrm{dm}^{-3} \mathrm{NAA}$ and $0.7 \mathrm{mg} \mathrm{dm}^{-3}$ BA proved less favourable (Table 1). The mass-propagation stage in the presence of NAA and BA lasted for 5 months. During this time, 150 decontaminated seeds yielded 1019 rooted micro-plants. Of these 904 survived the hardening stage (Fig. 2a). The same number of 150 aseptic seedlings grown in the propagation medium with IBA and BA yielded 1110 of micro-plants (Table 1), of which 1022 survived to be planted in experimental field plots (Fig. 2a-d). Bladder campion shoots rooted easily and abundantly regardless of the medium. Mean number of regenerated roots varied from 11 to over 12 per shoot. Anatomical verification of $S$. vulgaris organs evaluated usability of the obtained material for further growth and development in the metal contaminated site. Adventitious roots initiated and regenerated on the rooting medium showed normal primary cortex to vascular tissue ratio and proper differentiation of vascular elements (data not shown). After transplanting the regenerated micro-plants to the substrate, the roots easily undertook their physiological function. The plant material was successfully
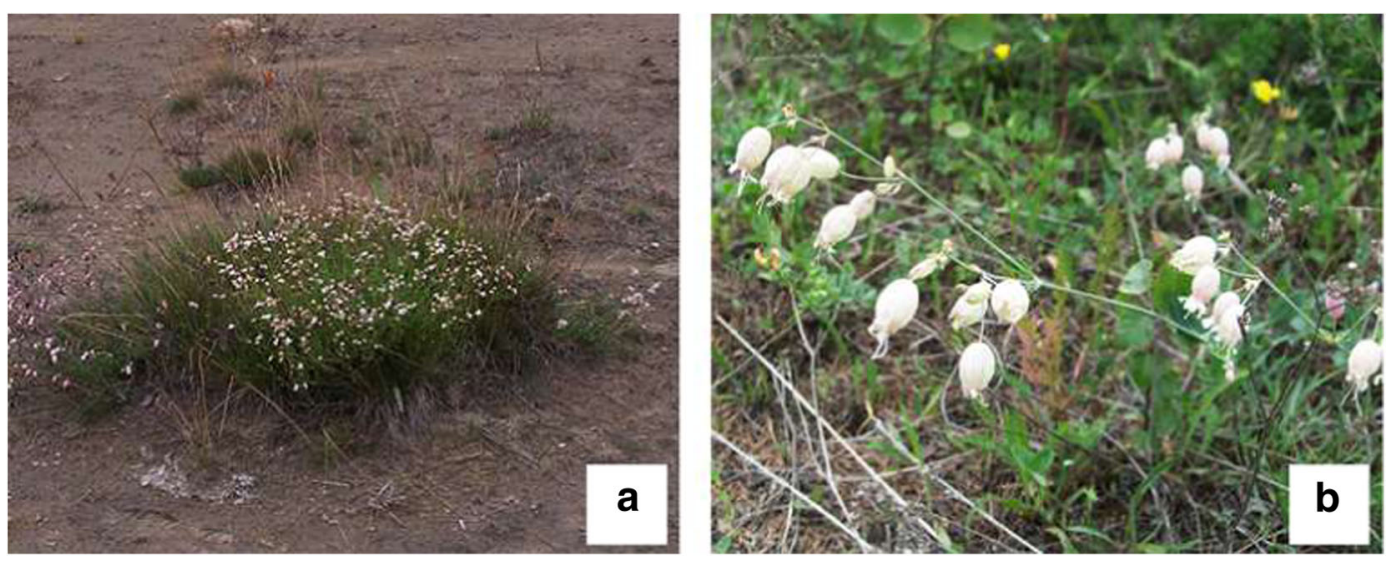

Fig. 1 a Growth habitat of Silene vulgaris ecotype from Olkuski Zinc-Lead Ore District, b Blooming shoots 
Fig. 2 Silene vulgaris plants acclimatized to the cultivation conditions: $\mathbf{a}$ and $\mathbf{b}$ juvenile plants transferred to the greenhouse, $\mathbf{c}$ and $\mathbf{d}$ pot cultivation in post-flotation wastes and in garden soil respectively, e and $\mathbf{f}$ plant cultivation on a shelf of settling pond of post-flotation wastes
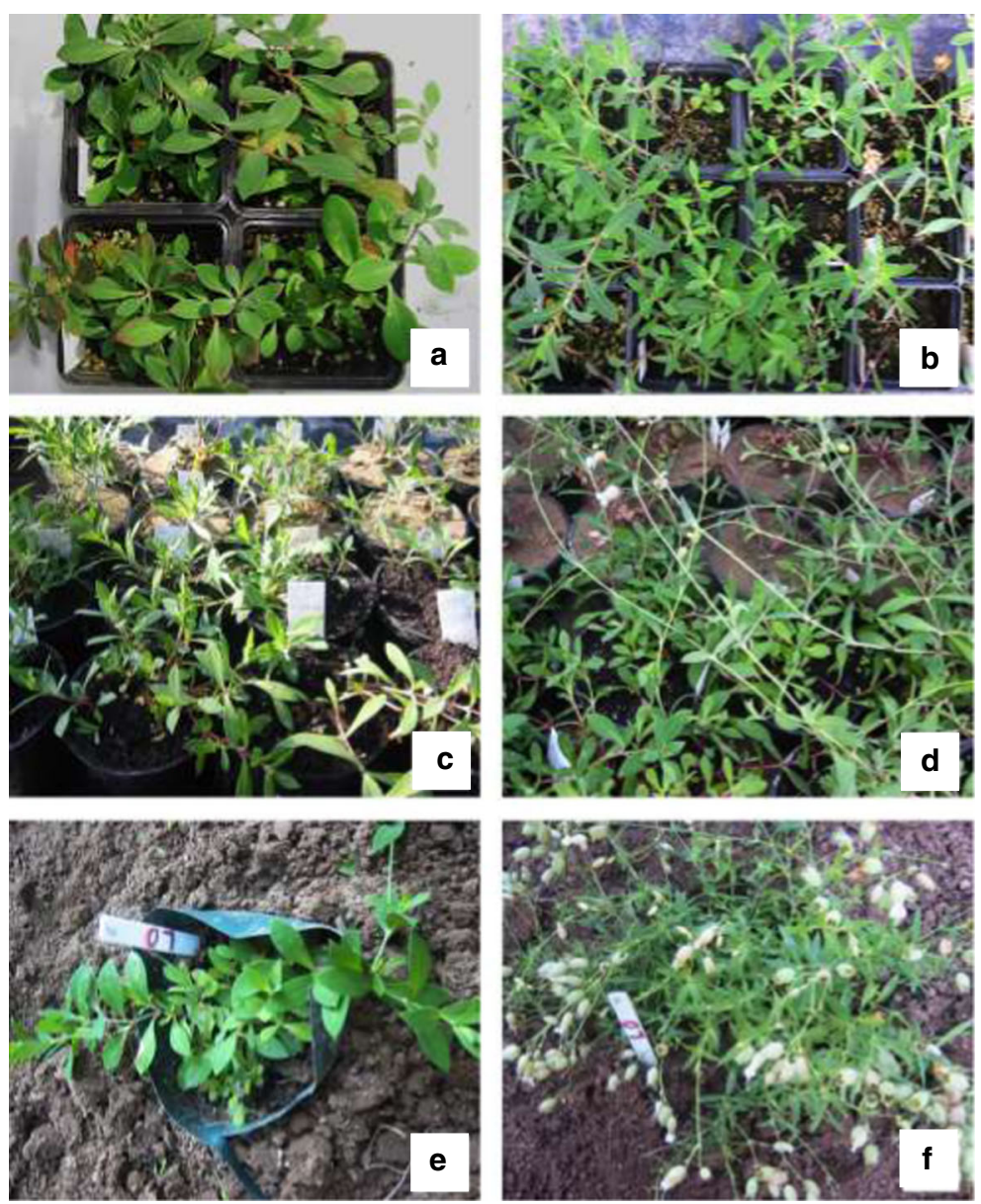

acclimatized to ex vitro growing conditions (Fig. 2a-f) in a greenhouse. The plants from the experimental population were similar to the control ones obtained directly from seeds sown in greenhouse conditions. In conclusion, in vitro micropropagation requires very little space and it allows for rapid production of numerous plantlets ready to be used ex vitro after a short hardening period.

Field experiment - substrate properties

FW alkaline reaction ( $\mathrm{pH}=7.4$ ), resulting from the dolomitic ore bearing rock, decreased insignificantly after 10 years of $S$. vulgaris cultivation (Table 2). The species cultivation caused also a gradual increase in organic $\mathrm{C}$ content from a very low value in FW $(0.66 \%)$, insignificantly higher in $0-10 \mathrm{~cm}$ layer of FW1S $(0.78 \%)$, to significantly higher in both analyzed layers of FW10S $1.38 \%$ in $0-10 \mathrm{~cm}$ and $1.12 \%$ in $10-30 \mathrm{~cm}$ layer. Total $\mathrm{N}$ contents followed the same pattern but significant increment of $\mathrm{N}$ in the top layer vs. its content in FW was observed already after 1 year of Silene growth (FW1S), followed by further increase at the end of the experiment (FW10S). Control objects (FW1 and FW10) showed insignificant increase in organic $\mathrm{C}$ and total $\mathrm{N}$ when compared with FW. Substantial changes in the substrate properties occurred for $\mathrm{C} / \mathrm{N}$ ratio, which amounted to 20.6 in FW and dropped in FW1S to 16.3 and $17.1 \mathrm{in} 0-10 \mathrm{~cm}$ and $10-30 \mathrm{~cm}$ layers, respectively. The lowest $\mathrm{C} / \mathrm{N}$ ratios, similar to those found in natural soils, were established in the substrate after 10 years of S. vulgaris cultivation (FW10S). They amounted to 11.5 in the top layer and 12.4 in the deeper layer (Table 2). Similarly to C and N contents, control samples without plant cover (FW1 and FW10) showed insignificant changes in $\mathrm{C} / \mathrm{N}$ ratio vs. $\mathrm{FW}$.

Bladder campion plants were cultivated without any fertilization, so as a result of its growth the substrate lost many macronutrients, which was especially visible after 
Table 2 Selected properties of the substrate used in the experimental scheme

\begin{tabular}{|c|c|c|c|c|c|}
\hline Substrate & Depth $^{1}$ & $\mathrm{pH}_{\mathrm{H} 2 \mathrm{O}}$ & $\mathrm{C}^{2}$ & $\mathrm{~N}^{3}$ & $\mathrm{C} / \mathrm{N}$ \\
\hline $\mathrm{FW}^{4}$ & $0-30$ & $7.4^{\mathrm{a}} \pm 0.2$ & $0.66^{\mathrm{a}} \pm 0.05$ & $0.032^{\mathrm{a}} \pm 0.001$ & $20.6^{\mathrm{c}} \pm 0.9$ \\
\hline \multirow[t]{2}{*}{$\mathrm{FW}_{1 \mathrm{~S}^{5}}$} & $0-10$ & $7.4^{\mathrm{a}} \pm 0.3$ & $0.78^{\mathrm{a}} \pm 0.06$ & $0.048^{\mathrm{b}} \pm 0.002$ & $16.3^{\mathrm{b}} \pm 0.8$ \\
\hline & $10-30$ & $7.4^{\mathrm{a}} \pm 0.2$ & $0.70^{\mathrm{a}} \pm 0.05$ & $0.041^{\mathrm{a}} \pm 0.002$ & $17.1^{\mathrm{b}} \pm 0.7$ \\
\hline $\mathrm{FW} 1^{6}$ & $0-30$ & $7.4^{\mathrm{a}} \pm 0.1$ & $0.67^{\mathrm{a}} \pm 0.02$ & $0.035^{\mathrm{a}} \pm 0.001$ & $19.2^{\mathrm{c}} \pm 0.2$ \\
\hline \multirow[t]{2}{*}{$\mathrm{FW}_{10 \mathrm{~S}^{7}}$} & $0-10$ & $7.2^{\mathrm{a}} \pm 0.1$ & $1.38^{\mathrm{c}} \pm 0.05$ & $0.120^{\mathrm{d}} \pm 0.004$ & $11.5^{\mathrm{a}} \pm 0.6$ \\
\hline & $10-30$ & $7.3^{\mathrm{a}} \pm 0.2$ & $1.12^{\mathrm{b}} \pm 0.04$ & $0.090^{\mathrm{c}} \pm 0.003$ & $12.4^{\mathrm{a}} \pm 0.5$ \\
\hline FW10 $0^{8}$ & $0-30$ & $7.4^{\mathrm{a}} \pm 0.1$ & $0.68^{\mathrm{a}} \pm 0.01$ & $0.034^{\mathrm{a}} \pm 0.002$ & $19.7^{\mathrm{c}} \pm 1.0$ \\
\hline
\end{tabular}

${ }^{1}$ in $\mathrm{cm},{ }^{2,3}$ in $\%,{ }^{4}$ flotation wastes (FW) before the experiment, ${ }^{5} \mathrm{FW} 1 \mathrm{~S}$ flotation wastes after 1 year of $S$. vulgaris cultivation, ${ }^{6} \mathrm{FW} 1$ flotation wastes after 1 year, ${ }^{7} \mathrm{FW} 10 \mathrm{~S}$ flotation wastes after 10 years of $S$. vulgaris cultivation, ${ }^{8} \mathrm{FW} 10$ flotation wastes after 10 years

the first year of the experiment (Table 3). A significant decrease in $\mathrm{P}, \mathrm{K}$ and $\mathrm{Mg}$ contents in FW1S as compared with FW and FW1 occurred in $0-10 \mathrm{~cm}$ layer. After 10 years, these nutrients were still less abundant than in FW and FW10 but higher than in FW1S. P, K and Mg content in the flotation wastes where $S$. vulgaris was not cultivated (FW1 and FW10) gradually decreased with time but the changes were not significant as compared with FW. Flotation wastes before the experiment contained 15,765 mg Zn kg-1, $5980 \mathrm{mg} \mathrm{Pb} \mathrm{kg}^{-1}$ and $84.6 \mathrm{mg} \mathrm{Cd} \mathrm{kg}{ }^{-1}$. Cultivation of the studied $S$. vulgaris ecotype lowered the content of these elements. Significant reduction of $\mathrm{Zn}, \mathrm{Pb}$ and $\mathrm{Cd}$ occurred gradually by a final value of $23.3 \%$ for $\mathrm{Zn}, 23 \%$ for $\mathrm{Cd}$ and $3 \%$ for $\mathrm{Pb}$ in 0-10 cm layer (FW10S vs. FW10). In 10-30 cm layer the drop in $\mathrm{Zn}, \mathrm{Pb}$ and $\mathrm{Cd}$ content was much smaller than in the upper layer (Table 3). In the samples without plants (FW1 and FW10) insignificant reduction of trace metal levels was observed in relation to FW.

FW demonstrated exceptionally low activity of the studied enzymes, i.e. $0.27 \mathrm{mg}$ TPF kg ${ }^{-1} 24 \mathrm{~h}$ (DHA), $0.58 \mathrm{mg} \mathrm{N}-\mathrm{NH}_{4}{ }^{+} \mathrm{kg}^{-1} 24 \mathrm{~h}$ (Urea) and $0.08 \mathrm{mg}$ of inverted sugar $\mathrm{kg}^{-1} 24 \mathrm{~h}$ (Inv) (Fig. 3). These activities did not change significantly in the substrate without plant cover (FW1 and FW10). Contrary to that, DHA and Inv activity spiked after 10 years of the plant cultivation (FW10S). Urease activity also increased in the substrate with plant cultivation (especially in $0-10 \mathrm{~cm}$ layer), but the differences were not significant. We observed a strong positive correlation between the activity of all the enzymes and $\mathrm{C}$ and $\mathrm{N}$ content, and a negative correlation with $\mathrm{pH}, \mathrm{C} / \mathrm{N}, \mathrm{K}, \mathrm{Zn}, \mathrm{Pb}$ and $\mathrm{Cd}$ levels (Table 4). Enzyme activity index amounted to 0.23 in FW, 0.26 in FW1 and 0.31 in FW10. After one year of S. vulgaris cultivation (FW1S) it almost doubled as compared with FW and FW1 in $0-10 \mathrm{~cm}$ layer, while in FW10S it increased by over 10 times in the top layer and by about 8.5 times in the deeper layer vs. FW and FW10 (Fig. 3). We conducted factor analysis to explain main factors shaping substrate properties (Table 5). The screened plot and the Kaiser criterion identified three factors that explained $91.34 \%$ of the result variability with loads of variables $>0.7$. Factor FI contained $\mathrm{C}, \mathrm{N}$, DHA, Inv and EAI with positive charges and $\mathrm{C} / \mathrm{N}, \mathrm{K}$

Table 3 Nutrient and heavy metal contents $\left[\mathrm{mg} \mathrm{kg}^{-1}\right]$ in the experimental substrate

\begin{tabular}{llllllll}
\hline Substrate & Depth & $\mathrm{P}$ & $\mathrm{K}$ & $\mathrm{Mg}$ & $\mathrm{Zn}$ & $\mathrm{Pb}$ & $\mathrm{Cd}$ \\
\hline FW & $0-30$ & $18.18^{\mathrm{c}} \pm 4.3$ & $71.3^{\mathrm{c}} \pm 2.4$ & $64.5^{\mathrm{b}} \pm 8.5$ & $15765^{\mathrm{c}} \pm 220$ & $5980^{\mathrm{b}} \pm 96$ & $84.6^{\mathrm{b}} \pm 11.2$ \\
FW1S & $0-10$ & $5.81^{\mathrm{a}} \pm 0.9$ & $34.4^{\mathrm{b}} \pm 3.8$ & $48.3^{\mathrm{a}} \pm 3.2$ & $14015^{\mathrm{b}} \pm 150$ & $5885^{\mathrm{ab}} \pm 121$ & $80.0^{\mathrm{ab}} \pm 10.9$ \\
& $10-30$ & $12.25^{\mathrm{bc}} \pm 0.8$ & $68.3^{\mathrm{c}} \pm 3.8$ & $60.3^{\mathrm{ab}} \pm 8.5$ & $15568^{\mathrm{c}} \pm 210$ & $5949^{\mathrm{b}} \pm 114$ & $83.1^{\mathrm{b}} \pm 10.1$ \\
FW1 & $0-30$ & $18.01^{\mathrm{c}} \pm 4.0$ & $70.3^{\mathrm{c}} \pm 2.6$ & $62.1^{\mathrm{b}} \pm 6.7$ & $15748^{\mathrm{c}} \pm 221$ & $5960^{\mathrm{b}} \pm 108$ & $83.9^{\mathrm{b}} \pm 10.6$ \\
FW10S & $0-10$ & $12.05^{\mathrm{bc}} \pm 1.6$ & $27.7^{\mathrm{ab}} \pm 2.7$ & $59.2^{\mathrm{ab}} \pm 2.6$ & $12031^{\mathrm{a}} \pm 126$ & $5740^{\mathrm{a}} \pm 131$ & $63.0^{\mathrm{a}} \pm 9.9$ \\
& $10-30$ & $10.06^{\mathrm{ab}} \pm 1.4$ & $24.6^{\mathrm{a}} \pm 2.5$ & $57.3^{\mathrm{ab}} \pm 2.6$ & $13687^{\mathrm{b}} \pm 143$ & $5810^{\mathrm{ab}} \pm 115$ & $68.1^{\mathrm{ab}} \pm 8.9$ \\
FW10 & $0-30$ & $17.83^{\mathrm{c}} \pm 4.0$ & $68.0^{\mathrm{c}} \pm 2.4$ & $60.8^{\mathrm{b}} \pm 7.3$ & $15696^{\mathrm{c}} \pm 203$ & $5907^{\mathrm{ab}} \pm 106$ & $81.8^{\mathrm{b}} \pm 11.1$ \\
\hline
\end{tabular}



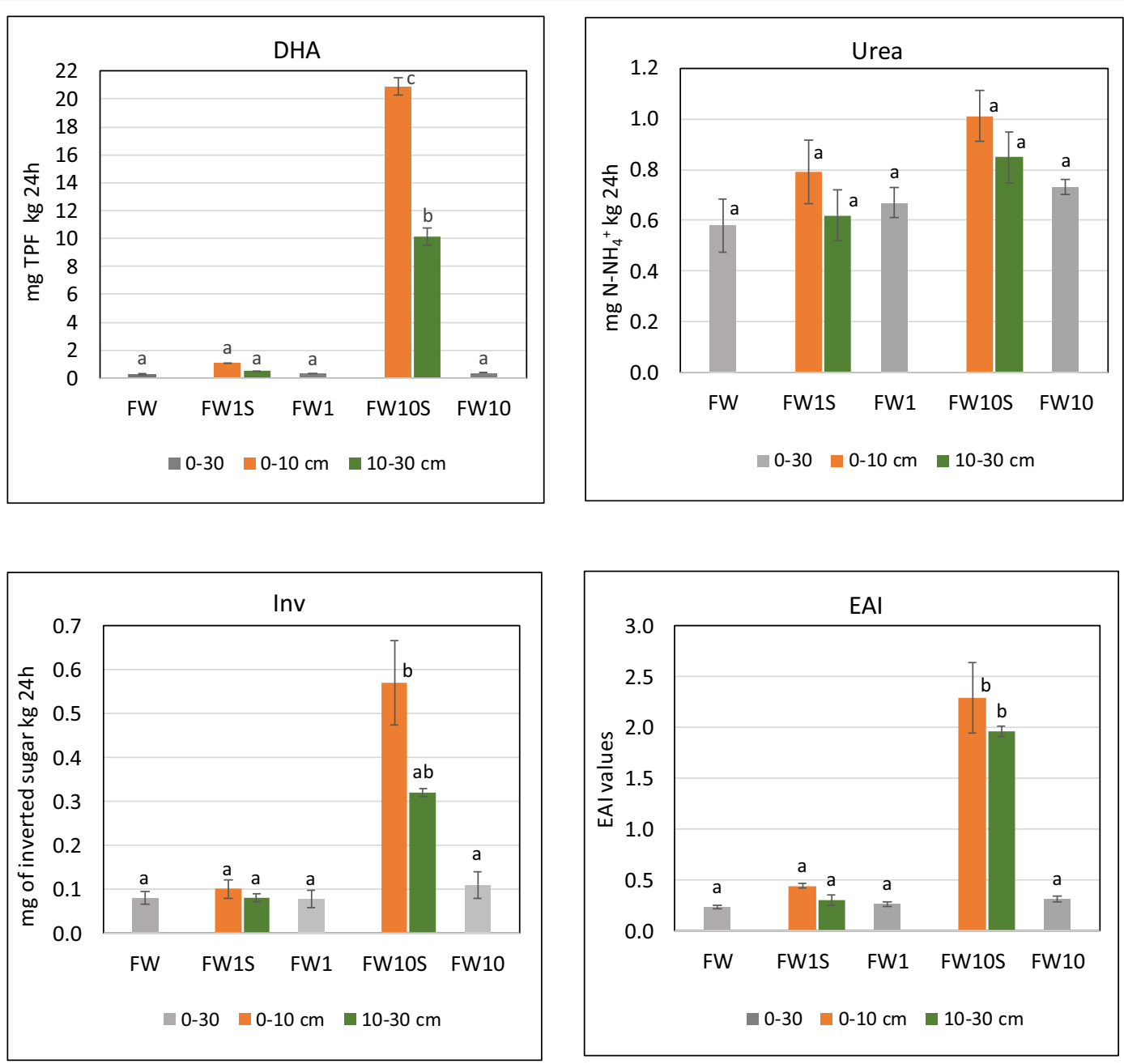

Fig. 3 Enzyme activity and enzyme activity index in the substrate. DHA - dehydrogenase activity, Inv - invertase activity, Urea - urease activity, EAI - enzyme activity index. FW - flotation waste before the experiment, FW1S- flotation

waste after the first growing period (with plants) and FW1 (without plants), FW10S flotation waste after 10 years -(with plants) and FW10 (without plants)

and $\mathrm{Zn}$ with negative charges. Factor FII contained P, $\mathrm{Mg}$ and $\mathrm{Pb}$ charged positively, and factor FIII contained $\mathrm{pH}$ and $\mathrm{Cd}$ with positive charges.

Field experiment - plant analysis

Plants evaluated in the experimental field in the first growing period showed intense vegetative growth, high vitality (Fig. 2e), and abundant blooming in the generative phase (Fig. 2f). In such hostile conditions over $90 \%$ of $S$. vulgaris specimens survived. Mean weight of an individual plant during the first growing period was $4.13 \mathrm{~g}$ d.w., with roots accounting for $41 \%$ and shoots for $59 \%$. Mean weight of 10 year old plants

was $23.86 \mathrm{~g}$ d.w., with roots and shoots accounting for 49 and 51\%, respectively (Table 6). S. vulgaris accumulated more $\mathrm{Zn}$ and $\mathrm{Pb}$ in the roots than in the shoots independently of the time of plant assessing, while $\mathrm{Cd}$ accumulation was similar in both organs. The amounts of all three metals in plant tissues increased significantly after 10 years of plant cultivation as compared with the first year. After 10 years, metal content in the roots was about 2.4 times higher for $\mathrm{Zn}$ and $\mathrm{Cd}$, and 1.4 times higher for $\mathrm{Pb}$ than after 1 year of growing in $\mathrm{FW}$. For shoots, the amount of $\mathrm{Zn}, \mathrm{Pb}$ and $\mathrm{Cd}$ rose 2.2, 1.5, and 3.6 times, respectively, after ten vs. 10 year of plant growth. Translocation factor $\left(\mathrm{TF}^{1}\right)$ indicates the percentage of accumulated metal transferred to the above 
Table 4 Correlations between enzyme activity and abiotic substrate factors

\begin{tabular}{llll}
\hline & Dehydrogenase & Urease & Invertase \\
\hline $\mathrm{pH}$ & $-0.4659(0.033)^{*}$ & $-0.6857(0.001)^{*}$ & $-0.5259(0.014)^{*}$ \\
$\mathrm{C}$ & $0.9737(0.000)^{*}$ & $0.6283(0.000)^{*}$ & $0.8928(0.000)^{*}$ \\
$\mathrm{~N}$ & $0.9782(0.000)^{*}$ & $0.6669(0.001)^{*}$ & $0.9044(0.000)^{*}$ \\
$\mathrm{C} / \mathrm{N}$ & $-0.8651(0.000)^{*}$ & $-0.7155(0.000)^{*}$ & $-0.8172(0.000)^{*}$ \\
$\mathrm{P}$ & $-0.2665(0.243)$ & $-0.4568(0.057)$ & $-0.2865(0.208)$ \\
$\mathrm{K}$ & $-0.7475(0.000)^{*}$ & $-0.6800(0.001)^{*}$ & $-0.7188(0.000)^{*}$ \\
$\mathrm{Mg}$ & $-0.0808(0.728)$ & $-0.3911(0.080)$ & $-0.1552(0.502)$ \\
$\mathrm{Zn}$ & $-0.9023(0.000)^{*}$ & $-0.7078(0.000)^{*}$ & $-0.8552(0.000)^{*}$ \\
$\mathrm{~Pb}$ & $-0.5980(0.004)^{*}$ & $-0.4751(0.042)^{*}$ & $-0.4806(0.027)^{*}$ \\
$\mathrm{Cd}$ & $-0.6714(0.001)^{*}$ & $-0.7014(0.000)^{*}$ & $-0.7332(0.000)^{*}$ \\
\hline
\end{tabular}

Each value represent $r$ with the $p$ value in parenthesis

Correlations were based on three samples from FW, FW1S, FW1, FW10S, and FW10 substrates $(n=21)$

Significant correlations at $p \leq 0.05$ are marked with ${ }^{(*)}$

ground organs (Zhang et al. 2010). $\mathrm{TF}^{1}$ calculated after one growing season was similar for all metals and amounted to about $40 \%$. $\mathrm{TF}^{1}$ calculated after 10 years of $S$. vulgaris cultivation was the lowest for $\mathrm{Pb}(43 \%)$, while for $\mathrm{Zn}$ it amounted to $46 \%$. Ten years old bladder

Table 5 Matrix of rotation of standardized factor charges approached by the Varimax method of studied substrate properties. The table included only factor loads $>0.7$

\begin{tabular}{llll}
\hline Variable & FI & FII & FIII \\
\hline $\mathrm{pH}$ & & & 0.905 \\
$\mathrm{C}$ & 0.959 & & \\
$\mathrm{~N}$ & 0.938 & & \\
$\mathrm{C} / \mathrm{N}$ & -0.810 & & \\
$\mathrm{P}$ & & 0.942 & \\
$\mathrm{~K}$ & -0.733 & & \\
$\mathrm{Mg}$ & & 0.932 & \\
$\mathrm{Zn}$ & -0.829 & & \\
$\mathrm{~Pb}$ & & 0.702 & \\
$\mathrm{Cd}$ & & & 0.783 \\
$\mathrm{DHA}$ & 0.905 & & \\
Ure & & & \\
Inv & 0.814 & & \\
EAI & 0.864 & & \\
Eigenvalues & 9.39 & 2.19 & 1.20 \\
Cumulative variance \% & 67.07 & 82.74 & 91.34 \\
\hline
\end{tabular}

campion plants transferred $50 \%$ of the accumulated $\mathrm{Cd}$ into their shoots (Table 7). Yoon et al. (2006) claimed that the translocation factor $\left(\mathrm{TF}^{2}\right)$ for $\mathrm{Zn}$ and $\mathrm{Pb}$ did not differ much between the sampling terms. For $\mathrm{Zn}$ and $\mathrm{Pb}$, both $\mathrm{TF}^{2}$ and $\mathrm{BCF}$ were below one. $\mathrm{TF}^{2}$ for $\mathrm{Cd}$ was low after the first growing season, while after 10 years it reached 0.98. BCF for $\mathrm{Cd}$ in roots reached 1.42 and was almost the same for shoots (1.4) (Table 7).

\section{Discussion}

Efficacy of vegetative propagation and suitability of plant material for field conditions

Recent years have brought many valuable studies on different aspects of agrobiotechnology (Fotlz et al. 2000; Moeen and Agraval 2017), where scientific teams' leaders were ambitious enough to achieve far-reaching aims in the near future (Bell et al. 2018). Desirable effects were frequently produced, also in micropropagation of vascular plants of different taxonomic origin (Citadelli et al. 2017; Muszyńska and Hanus-Fajerska 2017; Corteés-Olmos et al. 2018; Suárez et al. 2018). Future prospects depend on successful improvement of the techniques used for obtaining genotypes with enhanced tolerance to abiotic stresses (Wang et al. 2003; Clemens 2017). Further progress in this field requires cooperation of competent teams. Another prerequisite is refining tissue and cell culture methodology. Our results indicate a possibility of using in vitro methods in the remediation scheme of polluted industrial wastes. Vegetative propagation either under in vitro conditions or in the greenhouse should be adopted especially for seeds with reduced germination capacity or seedlings with low survival frequency. Those are standard solutions in horticultural practice and protection of floristic diversity ex situ in the case of valuable cultivars (Klavina et al. 2004; Citadelli et al. 2017; Salama et al. 2018). Elaboration of protocols to ensure efficient masspropagation of populations growing in the wild is of vital importance. It also concerns numerous populations representing calamine flora or valuable metallophytes (Li et al. 2010; Hanus-Fajerska et al. 2012; Muszyńska and Hanus-Fajerska 2017; Muszyńska et al. 2018a, b). Publications concerning propagation of herbaceous species or vascular plants are more numerous than those reporting proliferative cultures of metallophytes. The latter have been obtained in Europe (Dal Corso et al. 
Table 6 Dry mass and metal concentration in S. vulgaris organs evaluated after 1 and 10 years of cultivation on post-flotation tailings

\begin{tabular}{llllll}
\hline Experiment duration [years] & Plant organ & Dry mass ${ }^{*}[\mathrm{~g}]$ & & \multicolumn{2}{l}{ Metal concentration in S. vulgaris $\left[\mathrm{mg} \mathrm{kg}^{-1} \mathrm{~d} . \mathrm{w}.\right]$} \\
\cline { 4 - 6 } & & & $\mathrm{Zn}$ & $\mathrm{Pb}$ & $\mathrm{Cd}$ \\
\hline 1 & roots & $1.69^{\mathrm{a}} \pm 0.51$ & $3800^{\mathrm{b}} \pm 134$ & $250^{\mathrm{b}} \pm 18$ & $37.5^{\mathrm{a}} \pm 5.1$ \\
& shoots & $2.44^{\mathrm{a}} \pm 0.86$ & $3200^{\mathrm{a}} \pm 112$ & $180^{\mathrm{a}} \pm 12$ & $25.0^{\mathrm{a}} \pm 3.2$ \\
10 & roots & $11.71^{\mathrm{b}} \pm 2.65$ & $9200^{\mathrm{d}} \pm 231$ & $349^{\mathrm{c}} \pm 25$ & $91.4^{\mathrm{b}} \pm 4.4$ \\
& shoots & $12.15^{\mathrm{b}} \pm 2.86$ & $7100^{\mathrm{c}} \pm 214$ & $268^{\mathrm{b}} \pm 22$ & $89.3^{\mathrm{b}} \pm 8.3$ \\
\hline
\end{tabular}

* Mean content calculated per plant, $n=18$

2005; Jack et al. 2005; Vinterhalter et al. 2008; Muszyńska and Hanus-Fajerska 2017; Muszyńska et al. 2018b), Asia (Xu et al. 2008, 2009) and Australia (Bidwell et al. 2001; Bhatia et al. 2002). Initial plant material usually involves seeds, or more rarely shoot explants. Xu and co-workers (2008) experimented with a European population of Thlaspi caerulescens, and regenerated aseptic seedlings similarly as in our work.

Remediation potential of calamine ecotype of Silene vulgaris

The investigated ecotype of Silene vulgaris is well adapted to elevated levels of metallic elements in rhizosphere and

Table 7 Values of translocation factor (TF) and bioconcentration factor $(\mathrm{BCF})$ calculated for $\mathrm{Zn}, \mathrm{Pb}$ and $\mathrm{Cd}$ for $\mathrm{S}$. vulgaris growing on the experimental plots

\begin{tabular}{lll}
\hline Coefficients of $\mathrm{HM}$ transfer and concentration & $\begin{array}{l}\text { Duration of } \\
\text { experiment }\end{array}$ \\
\cline { 2 - 3 } & 1 year & 10 years \\
\hline $\mathrm{TF}_{\mathrm{Zn}}^{1}(\%)$ & 43 & 46 \\
$\mathrm{TF}_{\mathrm{Pb}}(\%)$ & 42 & 43 \\
$\mathrm{TF}_{\mathrm{Cd}}(\%)$ & 40 & 50 \\
$\mathrm{TF}^{2} \mathrm{Zn}$ & 0.84 & 0.77 \\
$\mathrm{TF}^{2}{ }_{\mathrm{Pb}}$ & 0.72 & 0.77 \\
$\mathrm{TF}^{2} \mathrm{Cd}$ & 0.67 & 0.98 \\
$\mathrm{BCF}_{\mathrm{Zn}}$ roots & 0.26 & 0.72 \\
$\mathrm{BCF}_{\mathrm{Zn}}$ shoots & 0.22 & 0.55 \\
$\mathrm{BCF}_{\mathrm{Pb}}$ roots & 0.04 & 0.06 \\
$\mathrm{BCF}_{\mathrm{Pb}}$ shoots & 0.03 & 0.05 \\
$\mathrm{BCF}_{\mathrm{Cd}}$ roots & 0.47 & 1.42 \\
$\mathrm{BCF}_{\mathrm{Cd}}$ shoots & 0.31 & 1.40 \\
\hline
\end{tabular}

to growing in dry and nutrient-poor habitats (Wierzbicka and Panufnik 1998; Sandner and Matthies 2016, 2018; Koźmińska et al. 2018). In recent years, research attention has been focused on both phytoremediation potential of metallophytes or metalliferous site adapted plants and their restoration potential (Alvarez et al. 2003; Chigbo et al. 2013; Ciarkowska et al. 2016, 2017; JamaliHajiani et al. 2017). The main plant-based technologies used for reclamation of metal-polluted sites include phytoextraction and phytostabilization (Chigbo et al. 2013). The latter is used for large contaminated areas where no other more effective solutions are planned in the near future, and when the key challenge is to prevent penetration of harmful elements into groundwater (Doumas et al. 2018). The process of phytoextraction generally requires translocation of trace metals or metalloids to easily harvestable plant parts, i.e. shoots. Some tolerant plants tend to restrict soil-root and root-shoot transfers, and therefore accumulate low amounts of metals, while hyperaccumulators actively take up and translocate metals into their aboveground organs. Plants with TF and particularly BCF values below one are unsuitable for phytoextraction but may be efficient in phytostabilization schemes (Yoon et al. 2006; Ferreyroa et al. 2018). Our experiments with $S$. vulgaris calamine population showed that both $\mathrm{Zn}$ and $\mathrm{Cd} \mathrm{TF}$ coefficients were too low to use this species for effective phytoextraction. Furthermore, we confirmed our assumption that lead was excluded from $S$. vulgaris shoots. Nevertheless, $\mathrm{TF}^{1}$ calculated after one growing season was similar for all studied metals and amounted to about 40\%. After 10 years, this coefficient was the lowest for $\mathrm{Pb}$, (43\%) while for $\mathrm{Zn}$ it amounted to $46 \%$, and for $\mathrm{Cd}$ to $50 \%$ of total Cd content accumulated in the plant. Both translocation factor $\mathrm{TF}^{2}$ and bioconcentration factor (BCF) for $\mathrm{Zn}$ and $\mathrm{Pb}$ did not differ much in particular 
terms of plant sampling. Moreover, both factors for these metals were below $1 . \mathrm{TF}^{2}$ for $\mathrm{Cd}$ was low after the first growing season, while after 10 years it was close to one. $\mathrm{BCF}$ for $\mathrm{Cd}$ in the roots amounted to 1.42 , and to our surprise, it was almost the same (1.4) in the shoots. Translocation factor according to Zhang et al. (2010) is stricter than usually used TF expressing simply the shoot to root ratio for a given metal. In our opinion, TF that indicates percentage content of particular metal transferred to the above ground organs cannot be overestimated.

Effects of $S$. vulgaris cover on biochemical and chemical properties of tailings

Suitability of $S$. vulgaris for stabilizing flotation tailings was also evaluated based on the effect the species exerted on the flotation wastes characteristics. We performed factor analysis (FA) to establish main factors shaping the substrate properties. FA revealed three distinct associations between the variables. The first factor (FI) represented C, N, DHA, Inv and EAI with positive charges proving a relationship between these parameters, as the transformation of organic matter components depends on microorganisms. According to Frouz et al. (2008) and Ciarkowska et al. (2016) accumulation and decomposition of organic matter, and thus an increase in $\mathrm{C}$ and $\mathrm{N}$ content, are major steps of the soil formation process on post-mining sites. The process starts with a formation of humus layer that provides a habitat for microorganisms. This results in an increase of their activity manifested by enhanced DHA and Inv activities. DHA, as an intracellular enzyme, reflects overall microbial activity (Watts et al. 2010), while Inv is responsible for the soil ability to break down sucrose and free simple sugars that are the main energy sources for soil microorganisms (Frankenberger and Johanson 1983). As soil microflora forms an integral component of the ecosystem, its scarcity in metal wastes may result in very slow carbon and nutrient cycling (Tordoff et al. 2000). The presence of enzymes in the first association (FI) emphasized also the role of metal tolerant bacteria that promote plant growth and thus soil formation. Such bacteria are adapted to metal contaminated sites by means of their internal cell modifications and/or the ability to bind or precipitate metals inside or outside their cells (Pacwa-Płociniczak et al. 2018). The structure and diversity of microbial community is affected by both substrate contamination with metals and S. vulgaris root exudates that stimulate or inhibit growth of specific bacterial populations. According to PacwaPłociniczak (2018), long-term cultivation of $S$. vulgaris at metal contaminated sites may more strongly affect the microbial community structure than metal contamination. FI contained also $\mathrm{C} / \mathrm{N}$ ratio, $\mathrm{K}$ and $\mathrm{Zn}$ with negative loadings. A decrease in $\mathrm{C} / \mathrm{N}$ ratio to values similar to those found in natural soils confirms the soil formation on wastes, whereas a decrease in $\mathrm{K}$ and $\mathrm{Zn}$ amounts results from their uptake by $S$. vulgaris. Potassium originated from mineral parts of waste rocks. It is often taken in high amounts by plants growing in harsh conditions, as it contributes to the survival of plants exposed to various biotic and abiotic stresses (Wang et al. 2013). A drop in Zn was due to its accumulation by $S$. vulgaris, which demonstrated the species suitability for growing on $\mathrm{Zn}-\mathrm{Pb}$ flotation wastes. This allows us to define this factor as the effect of $S$. vulgaris capability of starting soil formation on flotation tailings. The factor explains about $67 \%$ of total variability, which makes it the crucial one. The second factor (FII), which explains $15.7 \%$ of total variability, contains $\mathrm{P}, \mathrm{Mg}$ and $\mathrm{Pb}$, present in similar amounts in the analyzed substrates (FW, FW1, FW1S, FW10 and FW10S). Correlation between P, $\mathrm{Mg}$ and other substrate properties, especially soil enzymes was low. Although $\mathrm{Pb}$ negatively correlates with enzyme activity, its phytotoxicity is usually much lower than that of $\mathrm{Zn}$ and $\mathrm{Cd}$ due to its limited bioavailability and uptake from the growth substrate (Hladun et al. 2015). Therefore, the second factor (FII) represents substrate properties that are rather unchangeable, irrespective of the period of $S$. vulgaris cultivation. The third factor (FIII) describes only $\mathrm{pH}$ and $\mathrm{Cd}$, explaining $8.6 \%$ of the total variability. It may be associated with $\mathrm{Cd}$ mobility and its uptake regulated by $\mathrm{pH}$. Cadmium is chemically similar to zinc, which is an essential micronutrient, and is therefore easily accumulated by plants. $\mathrm{Cd}$ may replace $\mathrm{Zn}$ in certain enzymes, thus creating less stable protein complexes (Hladun et al. 2015). FA analysis indicated that $S$. vulgaris cover may facilitate soil formation on the tailings. As a result of the plant cultivation, we observed symptoms of the ecosystem recovery, despite persisting metal contamination. As restoring degraded lands involves also stimulation of soil-forming processes, we chose a substantial increment in the accumulation of organic carbon and total nitrogen, a decrease of $\mathrm{C} / \mathrm{N}$ ratio as well as an increase in enzyme activity resulting from $S$. vulgaris cultivation vs. flotation wastes without plant cultivation as criteria for successful beginning of soil formation. 


\section{Conclusions}

In this study we assessed suitability of in vitro cultures for the effective vegetative propagation of calamine Silene vulgaris ecotype with the aim to plant the propagated material on post flotation tailings. We managed to efficiently multiply the studied ecotype and to obtain true to type progeny. This way, we ascertained that this species can be useful in assisted succession on heavily polluted sites. Moreover, using the translocation and bioconcentration factors we demonstrated that such plant material is only capable of stabilizing contaminated areas. We also found that $S$. vulgaris cultivation facilitates soil formation on highly contaminated tailings. The beginning of pedogenic processes was mainly manifested by humus formation and increased microbial activity.

Acknowledgements This work was financially supported by the Ministry of Science and Higher Education of the Republic of Poland. Financing of research project NN 523206537 and cofinancing in the form of statutory activity granted to the Institute of Plant Biology and Biotechnology (DS-3504 ZBiFR/15-17) and to the Department of Soil Science and Soil Protection (DS-3138/ IGiA/15-17) are greatly acknowledged.

Open Access This article is distributed under the terms of the Creative Commons Attribution 4.0 International License (http:// creativecommons.org/licenses/by/4.0/), which permits unrestricted use, distribution, and reproduction in any medium, provided you give appropriate credit to the original author(s) and the source, provide a link to the Creative Commons license, and indicate if changes were made.

\section{References}

Alvarez E, Fernandez-Marcos ML, Vaamonde C, FernandezSanjurio MJ (2003) Heavy metals in the dump of an abandoned mine in Galicia (NW Spain) and in the spontaneously occurring vegetation. Sci Total Environ 313:185-197. https://doi.org/10.1016/S0048-9697(03)00261-4

Bell J, Paula L, Dodd T, Németh S, Nanou C, Mega V, Campos P (2018) EU ambition to build the world's leading bioeconomy - uncertain times demand innovative and sustainabe solutions. New Biotechnol 40:25-30. https://doi.org/10.1016/j. nbt.2017.06.010

Bhatia P, Bhatia NP, Ashwath N (2002) In vitro propagation of Stackhousia tyonii bailey (Stackhousiaceae); a rare and serpentine-endemic species of Central Queensland, Australia. Biodivers Conserv 11:1469-1477. https://doi. org/10.1023/A:1016252207054

Bidwell SD, Pederick JW, Somer-Knudsen J, Woodrow JE (2001) Micropropagation of the nickel hyperaccumulator Hybanthus floribundus (family Violaceae). Plant Cell Tissue Organ Cult 67:89-92. https://doi.org/10.1023/A:1011614202504

Cai Q, Long ML, Zhu M, Zhou MZ, Zhang L, Liu J (2009) Food chain transfer of cadmium and lead to cattle in a lead-zinc smelter in Guizhou, China. Environ Pollut 157:3078-3082. https://doi.org/10.1016/j.envpol.2009.05.048

Cassida LE, Klein DA, Santoro T (1964) Soil dehydrogenase activity. Soil Sci 98:371-376

Chardonnes AN, ten Bookum W, Kujiper DJ, Verkleij JAC, Ernst WHO (1998) Districbution of cadmium in leaves of cadmium tolerant and sensitive ecotypes of Silene vulgaris. Physiol Plant 104:75-80. https://doi.org/10.1034/j.13993054.1998.104011.x

Chigbo C, Batty L, Bartlet R (2013) Interactions of copper and pyrene on phytoremediation potential of Brassica juncea in copper-pyrene co-contaminated soil. Chemosphere 90:25422548. https://doi.org/10.1016/j.chemosphere.2012.11.007

Ciarkowska K (2017) Organic matter transformation and porosity development in non-reclaimed mining soils of different ages and vegetation covers: a field study of soils of the zinc and lead ore area in SE Poland. J Soils Sediments 17:2066-2079. https://doi.org/10.1017/s11368-017-1678-4

Ciarkowska K, Gambuś F (2005) Micromorphometric characteristics of upper layers of soils contaminated by heavy metals in the vicinity of a zinc and lead ore plant. Pol J Environ Stud 14(4):417-421

Ciarkowska K, Hanus-Fajerska E (2008) Remediation of soil-free grounds contaminated by zinc, lead and cadmium with the use of metallophytes. Pol J Environ Stud 17(5):707-712

Ciarkowska K, Sołek-Podwika K, Wieczorek J (2014) Enzyme activity as an indicator of soil-rehabilitation processes at a zinc and lead ore mining and processing area. J Environ Manag 132:250-256. https://doi.org/10.1016/j. envman.2016.12.028

Ciarkowska K, Gargiulo L, Mele G (2016) Natural restoration of soils on mine heaps with similar technogenic parent material: a case study of long-term soil evolution in Silesian-Krakow Upland Poland. Geoderma 261(1):141-150. https://doi. org/10.1016/j.geoderma.2015.07.018

Ciarkowska K, Hanus-Fajerska E, Gambuś F, Muszyńska E, Czech T (2017) Phytostabilization of $\mathrm{Zn}-\mathrm{Pb}$ ore flotation tailings with Dianthus carthusianorum and Biscutella laevigata after amending with mineral fertilizers or sewage sludge. J Environ Manag 189:75-83

Cichy K, Regula C, Pajor G (2016) Flotation of zinc and lead oxide minerals from Olkusz region calamine ores. E3S Web of Conf 8, 01042. https://doi.org/10.1051/e3 sconf $/ 2160801042$

Citadelli AD, Guariano F, Rodríguez D, Castiglione S (2017) In vitro propagation of Leucocroton havanensis Borhidi (Euphorbiaceae): a rare serpentine-endemic species of Cuba. Plant Biosyst 152:649-656. https://doi.org/10.1080 /11263504.2017.1311961

Clemens S (2017) How metal hyperaccumulating plants can advance $\mathrm{Zn}$ biofortification. Plant Soil 411:111-120. https://doi. org/10.1007/s11104-016-2920-3

Coppola V, Boni M, Gilg HA, Strzelska-Smakowska B (2009) Nonsulfide zinc deposits in the Silesian-Cracow district, Southern Poland. Mineral Deposita 44:559-480. https://doi. org/10.1007/s0126-008-0220-4 
Corteés-Olmos C, Guerrea-Ysasi G, Rodríguez-Burruezo A, Fita A (2018) In vitro germination and growth protocols of the ornamental Lohophora williamsi (Lem.) Coult. as a tool for protecting endangered wild populations. Sci Hortic 237:120127. https://doi.org/10.1016/j.scienta.2018.03.064

Dal Corso G, Borgato L, Furini A (2005) In vitro plant regeneration of the heavy metal tolerant hyperaccumulator Arabidopsis thaliana (Brassicaceae). Plant Cell Tissue Organ Cult 82: 267-270. https://doi.org/10.1007/s11240-005-1314-7

Dechamps C, Elvinger N, Meerts P, Lefèbre C, Escarré J, Colling G, Noret N (2011) Life history traits of the pseudometalophyte Thlaspi caerulescence in natural populations from northern Europe. Plant Biol 13(Suppl 1):125-135. https://doi.org/10.1111/j.1438-8677.2010.00387.x

Doumas P, Munoz M, Banni M, Becerra S, Brunnel O, Casiot C, Clyyet-Marel JC, Gardon J, Noack Y, Sappin-Didier V (2018) Pollymetallic pollution from abandoned mines in Mediterranean regions: a multidisciplinary approach to environmental risks. Reg Environ Chang 18:667-692. https://doi. org/10.1007/s10113-016-0939x

Ernst WHO, Nelissen HJM, Ten Bookum WM (2000) Combination toxicology of metal-enriched soils: physiological responses of a $\mathrm{Zn}$ - and $\mathrm{Cd}$ - resistant ecotype of Silene vulgaris on polymetallic soils. Environ Exp Bot 43:55-71

Farmer AA, Farmer AM (2000) Concentration of cadmium, lead and zinc in livestock feed organs around a metal production Centre in eastern Kazakstan. Sci Total Environ 257:53-60. https://doi.org/10.1016/S0048-9697(00)497-6

Ferreyroa GV, Gelma J, Sosa MD, Benitez MD, Orellana MA, Tudino MB, Lavado RS (2018) Brassica napus growth in lead-polluted soil: bioaccumulation in plant organs at different ontogenetic stages and lead fractionation in soil. Water Air Soil Pollut 229. https://doi.org/10.1007/s11270-0183851-9

Fotlz J, Barham B, Kim K (2000) Universities and agricultural biotechnology patent production. Agribusiness 16(1):82-95. https://doi.org/10.1002/(SICI)1520-6297(200024)16:1<82 $:: A I D-A G R>3.0 \mathrm{Co}: 2 \mathrm{~V}$

Frankenberger JR, Johanson JB (1983) Method of measuring invertase activity in soils. Plant Soil 74:301-311

Frouz J, Prach K, Pižl V, Hanel L, Starý J, Tajovský K, Materna J, Balık V, Kalčik J, Řehounková K (2008) Interactions between soil development, vegetation and soil fauna during spontaneous succession in post mining sites. Eur J Soil Biol 44:109-121. https://doi.org/10.1016/j.ejsobi.2007.09.002

Hagmann DF, Goodey NM, Mathieu C, Evans J, Aronson MFJ, Gallagher F, Adams Krumins J (2015) Effect of metal contamination on microbial enzymatic activity in soil. Soil Biol Biochem 91:291-297. https://doi.org/10.1016/j. soilbio.2015.09.012

Hanus-Fajerska E, Wiszniewska A, Muszyńska E (2012) In vitro multiplication and acclimatization of Biscutella laevigata (Brassicaceae) to cultivation in greenhouse condition. BioTech 93(2):97-101

Hladun KR, Parker DR, Trumble JT (2015) Cadmium, copper, and lead accumulation and bioconcentration in the vegetative and reproductive organs of Raphanus sativus: implications for plant performance and pollination. J Chem Ecol 41:386395. https://doi.org/10.1007/s10886-015-0569-7
Jack E, Atanasova S, Verkleij JA (2005) Callus induction and plant regeneration in the metallophyte Silene vulgaris (Caryophyllaceae). Plant Cell Tissue Organ Cult 80:25-31

Jamali-Hajiani NJ, Ghaderian SM, Karimi N, Schat H (2017) A comparison of antimony accumulation and tolerance among Ahillea wilhemsii, Silene vulgaris and Thlspi arvense. Plant Soil 412:267-281. https://doi.org/10.1007/s11104-0163064-1

Klavina D, Gailite A, Jacobsene G, Nečajeva J, Garvilova Ğ (2004) Tissue culture technology in conservation of threatened plant species in Latavia. Acta Univ Latv 676:183-188

Koźmińska A, Al Hassan M, Hanus-Fajerska E, Naranjo MA, Vicente O, Boscaiu M (2018) Comparative analysis of water deficit and salt tolerance mechanisms Silene. South African J Bot 117:193-206. https://doi.org/10.1016/j.sajb.2018.05.022

Li JT, Deng DM, Peng GT, Deng JC, Zang J, Liao B (2010) Successful micropropagation of the cadmium hyperaccumulator Viola baoshanensis (Violaceae). Int J Plant Phyt 12(8). https://doi.org/10.1080/1526510903390486

Moeen M, Agraval R (2017) Incubation of an industry: heterogeneous knowledge bases and modes of value capture. Strat Mgmt J 38:566-587. https://doi.org/10.1002/sjm.2511

Motyka J, d'Obryn K, Juśko K, Wójcik T (2017) Chemistry of water from the inflows to the "Franciszek" dipheading in the "Pomorzany" Zn-Pb mine in the Olkusz Area (SW Poland). J Sust Min 16:139-150. https://doi.org/10.1016/j. jsm.2017.11.002

Murashige T, Skoog F (1962) A revised medium for rapid growth and bio assays with tobacco tissue cultures. Physiol Plant 15: 473-497. https://doi.org/10.1111/j.1399-3054-1962. tb08052.x

Muszyńska E, Hanus-Fajerska E (2017) In vitro multiplication of Dianthus carthusianorum calamine ecotype with the aim to revegetate an stabilize polluted wastes. Plant Cell Tissue Organ Cult 128:631-640. https://doi.org/10.1007/s11240016-1140-0

Muszyńska E, Hanus-Fajerska E, Ciarkowska K (2018a) Studies on lead and cadmium toxicity in Dianthus carthusianorum calamine ecotype cultivated in vitro. Plant Biol 20:474-482. https://doi.org/10.1111/plb.12712

Muszyńska E, Hanus-Fajerska E, Koźmińska A (2018b) Differential tolerance to lead and cadmium in micropropagated Gypsophila fastigiata ecotype. Water Air Soil Pollut 229:42. https://doi.org/10.1007/s11270-018-3702-8

Nadgórska-Socha A, Ptasiński B, Kita A (2013) Heavy metal bioaccumulation and antioxidative responses in Cardaminopsis arenosa and Plantago lanceolata leaves from metalliferous and non-metalliferous sites: a field study. Ecotoxicology 22:1422-1433. https://doi.org/10.10007 /s10646-013-1129-y

Pacwa-Płociniczak M, Płociniczak T, Yu D, Kurola YM, Sinkkonen A, Piotrowska-Seget Z, Romantschuk M (2018) Effect of Silene vulgaris and heavy metal pollution on soil microbial diversity in long-term contaminated soil. Water Air Soil Pollut 229:13. https://doi.org/10.1007/s11270-0173655-3

Pardo J, Mondaca P, Celis-Diez JL, Ginocchio R, NavarroVillarroel C, Neaman A (2018) Assessment of revegetation of an acidic metal(loid)-polluted soils six years after the incorporation of lime with and without compost. Geoderma 331:81-86. https://doi.org/10.1016/j.geoderma.2018.06.018 
Paz-Ferreiro J, Gascó G, Gutiérrez G, Méndez A (2012) Soil biochemical activities and the geometric mean of enzyme activities after application of sewage sludge and sewage sludge biochar to soil. Biol Fertil Soils 48:511-517. https://doi.org/10.1007/s00374-011-3

Pierwoła J (2015) Using geoelectrical imaging to recognize $\mathrm{Zn}-\mathrm{Pb}$ post-mining waste deposits. Pol J Environ Stud 24: 2127-2137

Rola K, Osyczka P, Nobis M, Drozd P (2015) How do soil factors determine vegetation structure and species richness in postsmelting dumps? Ecol Eng 75:332-342. https://doi. org/10.1016/j.ecoleng.2014.11.026

Salama A, Popova E, Jones MP, Shukla MR, Fisk NS, Saxena PK (2018) Cryopreservation of the crtitically engangered golden paintbrush (Caseilleja levisecta Greenm.): from nature to cryobank to nature. In Vitro Cell Develop Biol - Plant. https://doi.org/10.1007/s.11627-018-9888-z

Sandner TM, Matthies D (2016) The effect of stress intensity and stress type on inbreeding depression in Silene vulgaris. Evolution 70(6):1225-1238. https://doi.org/10.1111 levo.12929

Sandner TM, Matthies D (2018) Inbreeding limits responses to environmental stress in Silene vulgaris. Environ Exp Bot 147:86-94. https://doi.org/10.1016/j.enveexpbot.2017.11.011

StatSoft Inc (2014) Poland. Statistica (data analysis software system), version 12.0. Tulsa

Suárez E, Alfayate C, Pérez-Francés J, Rodríguez-Pérez JA (2018) Structural and ultrastrucrural variations in in vitro and ex vitro rooting of microcuttings from two micropropagated Leucospermum (Proteaceae). Sci Hortic 239:300-307. https://doi.org/10.1016/j.scientia.2018.05.004

Sun Z, Xie X, Wang P, Hu Y, Cheng H (2018) Heavy metal pollution caused by small-scale metal ore mining activities: a case study from a polymetallic mine in South China. Sci Total Environ 639:217-227. https://doi.org/10.1016/j. scitotenv.2018.05.176

Szarek-Łukaszewska G, Grodzińska K (2011) Grasslands of a Zn$\mathrm{Pb}$ post-mining area (Olkusz ore-bearing region, S. Poland). Pol Bot J 56(2):245-260

Tabatabai MA, Brenner JM (1972) Assay of urease activity in soils. Soil Biol Biochem 4:479-487

Tordoff GM, Baker AJM, Willis AJ (2000) Current approaches to the revegetation and reclamation of metalliferous mine wastes. Chemosphere 41:219-228. https://doi.org/10.1016 /S0045-6535(99)00414-2
Vinterhalter B, Savič J, Platiša J, Raspor M, Ninkowić S, Mitić N, Vinterhalter D (2008) Nickel tolerance and hyperaccumulation in shoot cultures regenerated from hairy root cultures of Alyssum murale Waldst et Kit. Plant Cell Tissue Organ Cult 94:229-303. https://doi.org/10.1007/s11240-008-9343-7

Wang W, Vincur B, Altman A (2003) Plant responses to drought, salinity and extreme temperatures: towards genetic engineering for stress tolerance. Planta 218:1-14. https://doi. org/10.1017/s00425-003-1105-5

Wang M, Zheng Q, Shen Q, Guo S (2013) The critical role of potassium in plant stress response. Int J Mol Sci 14:73707390. https://doi.org/10.3390/ijms 14047370

Watts DB, Torbert HA, Feng Y, Prior SA (2010) Soil microbial community dynamics as influenced by composted dairy manure, soil properties, and landscape position. Soil Sci 175: 474-486

Wierzbicka M, Panufnik D (1998) The adaptation of Silene vulgaris to growth on a calamine waste heap. Environ Pollut 101:415-426

Woch MW, Stefanowicz AM, Stanek M (2017) Waste heaps left by historical $\mathrm{Zn}-\mathrm{Pb}$ ore mining are hotspots of species diversity of beech forest understory vegetation. Sci Total Environ 599-600:32-41. https://doi.org/10.1016/j. scitotenv.2017.04.197

Xu J, Zhang YX, Chai TY, Guan ZQ, Wei W, Han L, Cong L (2008) In vitro multiplication of heavy metals hyperaccumulator Thlaspi caerulescens. Biol Plant 52(1): 97-100

Xu J, Yin HX, Li X (2009) Protective effects of proline against cadmium toxicity in micropropagated hyperaccumulator Solanum nigrum L. Plant Cell Rep 28:325-333. https://doi. org/10.1007/s10535-008-0016-5

Yoon J, Cao X, Zhou Q, Ma LQ (2006) Accumulation of Pb, Cu, and $\mathrm{Zn}$ in native plants growing on a contaminated Florida site. Sci Total Environ 368:456-464. https://doi.org/10.1016 /j.scitoteenv.2006.01.016

Zhang Z, Rengel Z, Meney K (2010) Cadmium accumulation and translocation in four emergent wetland species. Water Air Soil Pollut 212:239-249. https://doi.org/10.1007/s11270010-0339-7

Publisher's note Springer Nature remains neutral with regard to jurisdictional claims in published maps and institutional affiliations. 